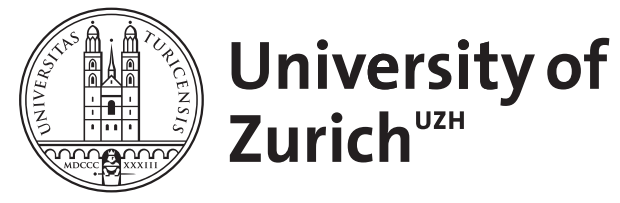

The Canon and the Cult: The emergence of book religion in Ancient Israel and the gradual sublimation of the temple cult

Schmid, Konrad

DOI: https://doi.org/10.2307/23488226

Posted at the Zurich Open Repository and Archive, University of Zurich ZORA URL: https://doi.org/10.5167/uzh-62781

Journal Article

Published Version

Originally published at:

Schmid, Konrad (2012). The Canon and the Cult: The emergence of book religion in Ancient Israel and the gradual sublimation of the temple cult. Journal of Biblical Literature, 131:291-307.

DOI: https://doi.org/10.2307/23488226 


\title{
The Canon and the Cult: The Emergence of Book Religion in Ancient Israel and the Gradual Sublimation of the Temple Cult
}

\author{
KONRAD SCHMID \\ konrad.schmid@uzh.ch \\ Universität Zürich, CH-8001 Zürich, Switzerland
}

The traditional distinction between cultic and book religions ${ }^{1}$ has fallen out of vogue because of its alleged privileging of literacy over orality and its indebtedness to a theological, evolutionary model. ${ }^{2}$ Nevertheless, it remains sufficiently clear that the religion of Judaism transitioned only gradually from a primarily "ritual coherence" to a primarily "textual" focus. ${ }^{3}$ This claim holds true even if these two aspects remain somewhat interdependent in some sense. The fact that this process

\footnotetext{
${ }^{1}$ See, e.g., the classic contributions of Siegfried Morenz ("Entstehung und Wesen der Buchreligion," TLZ 75 [1950]: 710-16; repr. in idem, Religion und Geschichte des alten Ägypten: Gesammelte Aufsätze [Cologne: Böhlau, 1975]) and Siegfried Hermann ("Kultreligion und Buchreligion: Kultische Funktionen in Israel und in Ägypten," in Das ferne und das nahe Wort: Festschrift Leonhard Rost zur Vollendung seines 70. Lebensjahres am 30. November 1966 [ed. Fritz Maass; Berlin: A. Töpelmann, 1967], 95-105), which promote this distinction.

${ }^{2}$ See the considerations of Jörg Rüpke, "Heilige Schriften und Buchreligionen: Überlegungen zu Begriffen und Methoden," in Heilige Schriften: Ursprung, Geltung und Gebrauch (ed. C. Bultmann et al.; Münster: Aschendorff, 2005), 191-204; and, in the same volume, Andreas A. Bendlin, “Wer braucht 'heilige Schriften?': Die Textbezogenheit der Religionsgeschichte und das 'Reden über die Götter' in der griechisch-römischen Antike," 205-28.

${ }^{3}$ See Jan Assmann, "Kulturelle Texte im Spannungsfeld von Mündlichkeit und Schriftlichkeit," in idem, Religion und Kulturelles Gedächtnis: Zehn Studien (Munich: Beck, 2000), 124-47, esp. 146. For Judaism as the first book religion, see Carsten Colpe, "Sakralisierung von Texten und Filiationen von Kanons," in Kanon und Zensur (ed. Aleida Assmann and Jan Assmann; Beiträge zur Archäologie der literarischen Kommunikation 2; Munich: Wilhelm Fink, 1987), 80-92; Jan Bremmer, "From Holy Books to Holy Bible," in Authoritative Scriptures in Ancient Judaism (ed. Mladen Popović; JSJSup 141; Leiden: Brill, 2010), 327-60, esp. 333-36.
} 
merits a detailed examination is likewise incontestable. One may therefore ask how texts took on functions that previously belonged to the cult during the emergence of book religion in ancient Israel? ${ }^{4}$

The following argument proceeds in four parts: (1) an assessment of the difference between biblical and historical perspectives on the Hebrew Bible's status as a sacred text; (2) an exploration of the historical situation of the canon's cult-related function following the loss of the temple in 70 C.E.; (3) an exploration of the similar historical situation resulting from the destruction of the First Temple in 587 B.C.E. and (4) a concluding summary.

\section{The Biblical versus the Historical View of the Hebrew Bible as Scripture}

As is often the case in biblical studies, the biblical portrayal of the formation of "scripture" is not identical to historical perspectives on this process. Generally speaking, the Hebrew Bible does not reason historical-critically but rather resultative-historically: it views historical processes in terms of their present repercussions. The Bible narrates that all Israel was in Egypt and all Israel experienced the exodus, but not because this was actually the case. In contrast, the reason for this presentation is so that the exodus will be regarded as the founding event for all Israel. The Pentateuch's interest in the past functions mythically inasmuch as its stories answer important questions by telling stories of origins. Thus, questions about why things are the way they are receive answers in terms of how they have come to be the way they are. A related corollary is that the more basic something is, the farther back the Bible anchors its origin in the biblical story.

To a certain extent this is true also for the Bible's self-presentation as "scripture." While the concept of "scripture" in the Bible is neither preexistent, that is, preceding the creation of the cosmos, nor an original element of the creation, it

\footnotetext{
${ }^{4}$ See further Frank Crüsemann, "Das 'portative' Vaterland," in Assmann and Assmann, Kanon und Zensur, 63-79; Odil H. Steck, "Der Kanon des hebräischen Alten Testaments: Historische Materialien für eine ökumenische Perspektive," in Vernunft des Glaubens: Wissenschaftliche Theologie und kirchliche Lehre (ed. J. Rohls and G. Wenz; Göttingen: Vandenhoeck \& Ruprecht, 1988), 231-52; repr. in Verbindliches Zeugnis 1: Kanon, Schrift, Tradition (ed. W. Pannenberg and T. Schneider; Dialog der Kirchen 7; Freiburg: Herder, 1992), 11-33; Jan Assmann, Fünf Stufen auf dem Wege zum Kanon: Tradition und Schriftkultur im frühen Judentum und in seiner Umwelt (Münsteraner Theologische Vorträge 1; Münster: LIT, 1999); Jürgen van Oorschot, "Altes Testament," in Heilige Schriften (ed. U. Tworuschka; Darmstadt: Wissenschaftliche Buchgesellschaft, 2000), 29-56; Konrad Schmid, Literaturgeschichte des Alten Testaments: Eine Einführung (Darmstadt: Wissenschaftliche Buchgesellschaft, 2008). See also Walter Burkert, "Zur Rolle der Schriftlichkeit in Kulten des Altertums," in Normieren, Tradieren, Inszenieren: Das Christentum als Buchreligion (ed. A. Holzem; Darmstadt: Wissenschaftliche Buchgesellschaft, 2004), 25-39.
} 
nevertheless emerges quite early in the story line of the Hebrew Bible, developing gradually from the book of Exodus onward. The Hebrew Bible thus reflects an awareness of the fact that Israel's religion did not begin as a book religion. The law was first given and written down under Moses, whereas the patriarchs of Genesis knew no law. ${ }^{5}$ Postdating the Hebrew Bible, the second-century в.c.E. book of Jubilees responds to this perceived "deficiency" by giving the heavenly tablets of the law to the patriarchs so that they might live in its light. ${ }^{6}$ However, the Bible itself anchors the law only as far back as the period of Moses, and this law was soon forgotten, reappearing only during Josiah's temple restoration (2 Kings 22-23). The law again fell into oblivion when catastrophe struck Judah and Jerusalem and was not reintroduced until the period of Ezra's leadership. In short: Moses bequeathed Israel the Jewish book religion that eventually found acceptance under Ezra. ${ }^{7}$

Such is the biblical perspective in its briefest form. However, biblical scholarship has determined that the religion of ancient Israel, viewed historically, developed only little by little into a book religion. According to this perspective the function of texts in the religious history of ancient Israel varied greatly, revealing a fourfold paradigmatic distinction among (a) religious texts; (b) normative texts; (c) scripture; and (d) a complete canon. Indeed, these functions seem to develop gradually and sequentially, but some of them also exist simultaneously alongside one another.

A religious text is one that functions as a regular component of the cult and is fully integrated in it. An example in the Hebrew Bible appears in Ps 24:7-10:

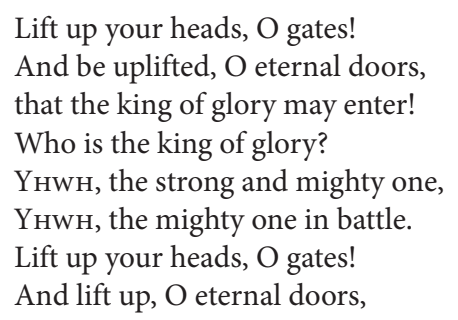

${ }^{5}$ On the retrojection of the notion of obedience to the Torah in texts such as Gen 22:1518; 26:3b-19, see Beate Ego, "Abraham als Urbild der Toratreue Israels: Traditionsgeschichtliche Überlegungen zu einem Aspekt des biblischen Abrahambildes," in Bund und Tora: Zur theologischen Begriffsgeschichte in alttestamentlicher, frühjüdischer und urchristlicher Tradition (ed. Friedrich Avemarie and Hermann Lichtenberger; WUNT 92; Tübingen, Mohr Siebeck, 1996), 25-40.

${ }^{6}$ On this motif, see Florentino García Martínez, "The Heavenly Tablets in the Book of Jubilees," in Studies in the Book of Jubilees (ed. Mathias Albani, Jörg Frey, and Armin Lange; TSAJ 65; Tübingen: Mohr Siebeck, 1997), 243-60.

${ }^{7}$ See further Jan Christian Gertz, "Moses und die Anfänge der jüdischen Religion," ZTK 99 (2002): 3-20.

${ }^{8}$ For the textual variant of 24:7 in the LXX, see Peter C. Craigie, Psalms 1-50 (WBC 19; Waco, Word Books, 1983), 210; for a probable preexilic setting of 27:7-10, see Frank L. Hossfeld and Erich Zenger, Die Psalmen (3 vols.; NEchtB; Würzburg: Echter, 1993), 1:157. 
This psalm clearly conveys its deep roots in the cult. It seems to have originally belonged in the cultic context of a procession-the entrance of God into the sanctuary-that is accompanied by a cultic antiphony.

In contrast, a normative text takes up a critical and prescriptive function with respect to the cult. Here the early, crucial beginnings of the transformation into book religion are visible. A biblical example of a normative text is the role of Deuteronomy in the book-finding story in 2 Kings 22-23. Whether the events in this narrative are historical is irrelevant for this point. ${ }^{9}$ What is crucial is the finding of a book-which, from the story's viewpoint, seems to be a reference to Deuteronomy - that bears normative status. ${ }^{10}$ According to the narrative sequence of 2 Kings 22-23, this book triggers Josiah's cultic reform and determines its nature. The story of the book's discovery claims a special origin for it. ${ }^{11}$ Its age, authorship, and background seem to have been left opaque in the interest of sacralizing the book and attributing to it the necessary authority over the cult.

Scholars widely agree that Deuteronomy probably belongs, in its literary core, near the end of the seventh century B.C.E., though there is some controversy about

\footnotetext{
${ }^{9}$ For various perspectives on the historicity of the report, see Hermann Spieckermann, Juda unter Assur in der Sargonidenzeit (FRLANT 129; Göttingen: Vandenhoeck \& Ruprecht, 1982); Christoph Uehlinger, "Gab es eine joschijanische Kultreform?" in Jeremia und die "deuteronomistische Bewegung" (ed. Walter Gross; BBB 98; Weinheim: Beltz Athenäum, 1995), 57-89; William G. Dever, "The Silence of the Text: An Archaeological Commentary on 2 Kings 23," in Scripture and Other Artifacts: Essays on the Bible and Archaeology in Honor of Philip J. King (ed. Michael D. Coogan et al.; Louisville: Westminster John Knox, 1994), 144-68; Martin Arneth, "Die antiassyrische Reform Josias von Juda: Überlegungen zur Komposition und Intention von 2Reg 23:4-15," ZABR 7 (2001): 189-216; Christoph Levin, "Joschija im deuteronomistischen Geschichtswerk," ZAW 96 (1984): 351-71; Herbert Niehr, "Die Reform des Joschija: Methodische, historische und religionsgeschichtliche Aspekte," in Gross, Jeremia und die "deuteronomistische Bewegung," 33-55; Lowell K. Handy, "Historical Probability and the Narrative of Josiah's Reform in 2 Kings," in The Pitcher Is Broken: Memorial Essays for Gösta W. Ahlström (ed. Steven W. Holloway and Lowell K. Handy; JSOTSup 190; Sheffield: Sheffield Academic Press, 1995), 25275. For the persons named in 22:12, see Mordechai Cogan and Hayim Tadmor, II Kings: A New Translation with Introduction and Commentary (AB 11; Garden City, NY: Doubleday, 1988), 282.

${ }^{10}$ For an overview of ancient identifications of the book found in 2 Kings 22 and Deuteronomy, see Hans-Peter Mathys, "Wilhelm Martin Leberecht de Wettes Dissertatio critico-exegetica von 1805," in Biblische Theologie und historisches Denken: Wissenschaftsgeschichtliche Studien aus Anlass der 50. Wiederkehr der Basler Promotion von Rudolf Smend (ed. Michael Kessler and Martin Wallraff; Studien zur Geschichte der Wissenschaften in Basel n.F. 5; Basel: Schwabe, 2008), $171-211$.

${ }^{11}$ See further Wolfgang Speyer, Bücherfunde in der Glaubenswerbung der Antike: Mit einem Ausblick auf Mittelalter und Neuzeit (Hypomnemata 24; Göttingen: Vandenhoeck \& Ruprecht, 1970).
} 
this issue. ${ }^{12}$ The assumption of a Mosaic background for the book in 2 Kings 2223 is probably to be explained historically as an attempt to legitimize and grant authoritative status to a contemporary text. Although it would be misleading to speak of a book religion in ancient Israel in the seventh century B.C.E., one can identify its beginnings in this period. Deuteronomy does not replace the cult but reforms it, seeking particularly to monopolize and centralize it. Its main precept declares both that only YHwH the God of Israel may be the object of worship and that the sole acceptable location for YHwH worship is the centralized sanctuary in Jerusalem. This program enthusiastically propagates the ideals of cultic unity and cultic purity. ${ }^{13}$ As an authoritative text in ancient Israel, Deuteronomy thus emerged initially not as a replacement but as a regulator of the cult. ${ }^{14}$ For the first time in the history of Israel and Judah, a text is used to bolster the authority of an institution, the centralized cult. This reverses the earlier pattern, in which texts became authoritative through their association with institutions. ${ }^{15}$ Nonetheless, Deuteronomy does not introduce a strict book religion; the cultic functions of Israel's religion remain dominant at this stage.

The dominance of cult religion generally continues for the entire Second Temple period (515 в.C.E. -70 C.E.), which is rightly regarded as the essential period of formation for the biblical books. The same time span also constitutes the most important period in the history of Israel for the sacrificial cult: daily sacrifices were the focal point of religious practice. It is difficult to say how the still-developing Hebrew Scriptures functioned during this period. Judging by the socioliterary cir-

${ }^{12}$ For a late-seventh-century date, see Bernard M. Levinson, Deuteronomy and the Hermeneutics of Legal Innovation (New York: Oxford University Press, 1997); Eckart Otto, Das Deuteronomium: Politische Theologie und Rechtsreform in Juda und Assyrien (BZAW 284; Berlin: de Gruyter, 1999); idem, Das Deuteronomium im Pentateuch und im Hexateuch (FAT 30; Tübingen: Mohr Siebeck, 2000). Interpreters opting for an exilic origin include Ronald E. Clements, "The Deuteronomic Law of Centralisation and the Catastrophe of 587 B.C.," in After the Exile: Essays in Honour of Rex Mason (ed. J. Barton and D. Reimer; Macon, GA: Mercer University Press, 1996), 5-25, esp. 7 n. 4 for earlier authors; Reinhard G. Kratz, Die Komposition der erzählenden Bücher des Alten Testaments (Uni-Taschenbücher 2157; Göttingen: Vandenhoeck \& Ruprecht, 2000), 137; Juha Pakkala, "The Date of the Oldest Edition of Deuteronomy," $Z A W 121$ (2009): 388-401. Pakkala's proposal is critically discussed by Nathan MacDonald, "Issues in the Dating of Deuteronomy: A Response to Juha Pakkala," ZAW 122 (2010): 431-35.

13 Theodor Oestreicher coined the German wordplay on "Kulteinheit" und "Kultreinheit"; see his Das deuteronomische Grundgesetz (Beiträge zur Förderung christlicher Theologie 27/4; Gütersloh: Bertelsmann, 1923), 144.

${ }^{14}$ See the discussion in Eckart Otto, "Ersetzen oder Ergänzen von Gesetzen in der Rechtshermeneutik des Pentateuch," in Die Tora: Studien zum Pentateuch. Gesammelte Aufsätze (Beihefte zur ZABR 9; Wiesbaden: Harrassowitz, 2009), 248-56.

${ }^{15}$ See David M. Carr, "Canonization in the Context of Community: An Outline of the Formation of the Tanakh and the Christian Bible," in A Gift of God in Due Season: Essays on Scripture and Community in Honor of James A. Sanders (ed. David M. Carr and Richrad D. Weis; JSOTSup 225; Sheffield: Sheffield Academic Press, 1996), 30 n. 24. 
cumstances (to the extent that they can be reconstructed), the chief readers of the Hebrew Scriptures were probably the very people who wrote them. In all likelihood only a few copies circulated prior to the Hellenistic period. ${ }^{16}$ During the Second Temple period, the Hebrew Scriptures probably served primarily to legitimate those groups within the Jerusalem temple who were responsible for the production and care of the Scriptures themselves. However, to conclude that these groups were homogeneous simply because they were all located in one geographical location would be completely mistaken. The Bible's inner diversity calls such a conclusion into question, as it owes its existence largely to the breadth of this milieu.

In comparison, the concept of scripture appears in the Hebrew Bible only in a few late passages. The concept of "scripture" here means a collection of authoritative texts attributed a certain sacrality, but not yet including notions of closedness and textual invariability. The idea that Torah reading itself is a form of cultic veneration appears clearly in Neh 8:5-8, a text arising from a setting proximate to synagogue worship and that, consequently, hardly fits a date before the second or third century B.C.E.: ${ }^{17}$

And Ezra opened the book in the sight of all the people, for he stood higher than all the people. As he opened it, the entire people stood. When Ezra praised YнwH, the great God, all the people responded, "Amen, Amen!" with their hands uplifted.18 They bowed and threw themselves down before Yнwн with their faces to the ground. ... So they read from the book, from the Torah of God. Section by section was read, enabling comprehension so that the people understood the reading.

Only following the abrupt and violent end of daily sacrifice as a result of the Romans' destruction of Jerusalem in 70 C.E. is it possible to say that Judaism, mainly shaped henceforth by the Pharisaic-rabbinic trajectory, transformed into a book religion. ${ }^{19}$ Quite diverse events such as the Maccabean crisis, the emergence of the

${ }^{16}$ See further Norbert Lohfink, "Gab es eine deuteronomistische Bewegung?" in Gross, Jeremia und die "deuteronomistische Bewegung," 313-82; repr. in idem, Studien zum Deuteronomium und zur deuteronomistischen Literatur III (SBAB 20; Stuttgart: Katholisches Bibelwerk, 1995); Konrad Schmid, Buchgestalten des Jeremiabuches: Untersuchungen zur Redaktions- und Rezeptionsgeschichte von Jer 30-33 im Kontext des Buches (WMANT 72; Neukirchen-Vluyn: Neukirchener Verlag, 1996), 35-43; and, differently, Ernst A. Knauf, "Les milieux producteurs de la Bible hebraïque," in Introduction à l' Ancien Testament (ed. T. Römer et al.; MdB 49; Geneva: Labor et Fides, 2004), 49-60.

${ }^{17}$ See Antonius H. J. Gunneweg, Nehemia (KAT; Gütersloh: Mohn, 1987), 112; Arie van der Kooij, "Authoritative Scriptures and Scribal Culture," in Popović, Authoritative Scriptures in Ancient Judaism, 55-71, esp. 62-63.

${ }^{18} \mathrm{LXX}^{\mathrm{B}}$ lacks "with their hands uplifted"; for the expression, see Ps 28:2.

${ }^{19} \mathrm{On}$ the issue of the different possibilities for assessing the continuity between the Pharisees and the rabbis, see Günter Stemberger, "Qumran, die Pharisäer und das Rabbinat," in Antikes Judentum und frühes Christentum: Festschrift für Hartmut Stegemann zum 65. Geburtstag (ed. Bernd Kollmann et al.; BZNW 97; Berlin: de Gruyter, 1998), 210-24. 
synagogue ${ }^{20}$ and the stylization of the Psalter as a literary sanctuary ${ }^{21}$ prepared the way for this process. However, the intellectual study of scripture completely took the place of the temple cult only after 70 C.E.: where the Torah is studied, no temple is necessary. ${ }^{22}$

Historically speaking, therefore, the emergence of book religion was a process that was fully concomitant with the literary development of the Hebrew Scriptures and that manifested itself in the shaping of a canon only after their literary completion. This processual emergence of book religion is, to some extent, inverse to the comparably processual disappearance of traditional cult religion elements that the emerging scripture gradually overtakes and integrates. ${ }^{23}$ The destruction of the temple in 587 в.C.E. and again in 70 C.E. catalyzed both of these processes. ${ }^{24}$ The first destruction served as a historical confirmation of the prophetic writings; the second, judging by the Psalter, apparently led to the understanding of the Ketuvim as a post-cultic complement of how to understand and apply the Law and the Prophets. The following discussion will treat these discernible stages of intellectual history, coinciding with the destruction of the two temples, in reverse historical order.

There is sufficient scholarly agreement that only in this period can we begin speaking of a Hebrew Bible canon. John Barton, for example, has appropriately pro-

${ }^{20}$ See Lester L. Grabbe, "Synagogues in Pre-70 Palestine: A Reassessment," in Ancient Synagogues: Historical Analysis and Archaeological Discovery (ed. Dan Urman and Paul V. M. Flesher; Studia Post-biblica 47.1; Leiden: Brill, 1995), 17-26; Paul V. M. Flesher, "Palestinian Synagogues before 70 C.E.: A Review of the Evidence," in ibid., 27-39; The Ancient Synagogue from Its Origins until 200 C.E.: Papers Presented at an International Conference at Lund University, October 14-17, 2001 (ed. Birger Olsson and Magnus Zetterholm; ConBNT 39; Stockholm: Almqvist \& Wiksell, 2003); see also Anders Runesson, The Ancient Synagogue from Its Origins to 200 C.E.: A Source Book (AGJU 72; Leiden: Brill, 2008).

${ }^{21}$ See Erich Zenger, "Der Psalter als Buch: Beobachtungen zu seiner Entstehung, Komposition und Funktion," in Der Psalter in Judentum und Christentum (ed. Erich Zenger; HBS 18; Freiburg: Herder, 1998), 1-57, esp. 35-48; repr. as "Der Psalter als Heiligtum," in Gemeinde ohne Tempel = Community without Temple: Zur Substituierung und Transformation des Jerusalemer Tempels und seines Kults im Alten Testament, antiken Judentum und frühen Christentum (ed. Beate Ego et al.; WUNT 118; Tübingen: Mohr, 1999), 115-30; idem, "'Ich liebe den Ort, da deine Herrlichkeit wohnt' (Ps 26:8): Tempeltheologische Semiotisierung des Alltags im Psalter," in Gottesstadt und Gottesgarten: Zu Geschichte und Theologie des Jerusalemer Tempels (ed. Othmar Keel and Erich Zenger; QD 191; Freiburg: Herder, 2002), 180-206; Bernd Janowski, "Ein Tempel aus Worten: Zur theologischen Architektur des Psalters," in The Composition of the Book of Psalms (ed. Erich Zenger; BETL 238; Leuven: Peeters, 2010), 279-306.

${ }^{22}$ See Stefan Schreiner, "Wo man Tora lernt, braucht man keinen Tempel: Einige Anmerkungen zum Problem der Tempelsubstitution in rabbinischen Judentum," in Ego, Gemeinde ohne Tempel, 371-92.

${ }^{23}$ See The Image of the Book: Iconic Cults, Aniconism, and the Rise of Book Religion in Israel and the Ancient Near East (ed. Karel van der Toorn; CBET 21; Leuven: Peeters, 1997).

${ }^{24}$ See Zerstörungen des Jerusalemer Tempels: Geschehen, Wahrnehmung, Bewältigung (ed. Johannes Hahn; WUNT 147; Tübingen: Mohr, 2002). 
posed a distinction between scripture and canon to mark this development. ${ }^{25}$ While prior to 70 C.E. "scripture," that is, an ensemble of authoritative writings, existed under the collective heading "the Law and the Prophets" or "Moses and the Prophets" (each with variations), there was still no canon in the sense of a self-contained list of binding documents, unchanging in their content and arranged in the three sections as Torah, Nevi'im, and Ketuvim (Law, Prophets, and Writings). ${ }^{26}$ The first references to a canon as a textually fixed, defined, and arranged stock of authoritative writings appear in Josephus, Philo, and 4 Ezra. ${ }^{27}$ No convincing textual evidence pointing to the period before 70 C.E. is available for a three-part structure of the Hebrew canon like the standard theory of interpreters such as Herbert E. Ryle and Frants Buhl,. ${ }^{28} \mathrm{Up}$ to this point the primary mark of authority for the texts in question was not their exclusivity but their eminence. ${ }^{29}$ Moreover, the biblical manuscripts from the Dead Sea provide evidence of a strikingly fluid textual tradition in the first century B.C.E.; there simply is no fixation of the letter of the text. ${ }^{30}$

${ }^{25}$ John Barton, Oracles of God: Perceptions of Ancient Prophecy in Israel after the Exile (London: Darton, Longman \& Todd, 1986), 57; Eugene Ulrich, "The Non-Attestation of a Tripartite Canon in 4QMMT," CBQ 65 (2003): 202-14; see already Willis J. Beecher, "The Alleged Triple Canon of the Old Testament," JBL 15 (1896): 118-28. In a comparable, though somewhat more technical, treatment, Gerald T. Sheppard has proposed the differentiation of "canon 1" and "canon 2" ("Canon," ER ?:62-69, esp. 64-67). Stephen B. Chapman (The Law and the Prophets: A Study in Old Testament Canon Formation [FAT 27; Tübingen: Mohr Siebeck, 2000], 283-85) proposes a similar distinction but with different profiles and much earlier datings. See further Lee M. McDonald, The Biblical Canon: Its Origin, Transmission, and Authority (3rd ed.; Peabody, MA: Hendrickson, 2007), 55-58; John J. Collins, "Before the Canon: Scriptures in Second Temple Judaism," in Old Testament Interpretation: Past, Present and Future: Essays in Honor of Gene M. Tucker (ed. James Luther Mays, David L. Petersen, and Kent Harold Richards; Nashville: Abingdon, 1995), 225-41, Collins uses the term "core canon" (p. 232).

${ }^{26}$ See, e.g., the two-part formulas in 1QS 1.1-2; 8.15-16; D 5.21-6.2; 4QDibHam (4Q504) frag. 2.3, 11-13; Matt 24:15; Luke 16:16, 29, 31; 24:27; Acts 26:22; 28:23; and Barton, Oracles, $44-46$.

${ }^{27}$ See the evidence in Peter Höffken, "Zum Kanonbewusstsein des Josephus Flavius in Contra Apionem und in den Antiquitates," JSJ 32 (2001): 159-77; Yehoshua Amir, "Authority and Interpretation of Scripture in the Writings of Philo," in Mikra: Text, Translation, Reading and Interpretation of the Hebrew Bible in Ancient Judaism and Early Christianity (ed. Martin Jan Mulder; CRINT 2.1; Assen: Van Gorcum, 1998), 421-53; Christian Macholz, "Die Entstehung des hebräischen Bibelkanons nach 4Esra 14," in Die hebräische Bibel und ihre zweifache Nachgeschichte: Festschrift für Rolf Rendtorff zum 65. Geburtstag (ed. Erhard Blum; Neukirchen-Vluyn: Neukirchener Verlag, 1990), 379-91.

${ }^{28}$ Ryle, The Canon of the Old Testament: An Essay on the Gradual Growth and Formation of the Hebrew Canon of Scripture (2nd ed.; 1895; repr., London: Macmillan, 1984); Buhl, Kanon und Text des Alten Testaments (Leipzig: Akademische Buchhandlung, 1891), 13-14.

${ }^{29}$ The well-known observation that NT writings such as Jude 14-15 could also cite, anachronistically speaking, an "apocryphal" texts such as $1 \mathrm{En}$. 1:9 shows that the basis of appeal was textual eminence not "canonical" exclusivity during this era.

${ }^{30}$ For a discussion of the significance of the Dead Sea findings for the status of the biblical texts at that time, see Eugene Ulrich, The Dead Sea Scrolls and the Origins of the Bible (Studies in 
Light retouching of the text was possible in the Pentateuch even as late as the Maccabean period. ${ }^{31}$

\section{The Postcultic Development of the Hebrew Bible Canon after the Destruction of Jerusalem in 70 C.e.}

What did the canonical Hebrew Bible look like after the Romans destroyed Jerusalem in 70 C.E., and what description befits the late stages of its formation? Is it possible to clarify the cult-replacing functions of the canon in relation to this event? To begin, a brief foray into the situation before 70 C.E. will provide a helpful comparison.

As already mentioned, the authoritative writings of the Hebrew Bible seem to reflect an essentially two-part division consisting of "Moses" (or the Law) and the Prophets during the NT period. This structure is important hermeneutically for all Scripture, revealing a predominant Torah and its historical application in the Prophets. In this period the Prophets seem to have included a more extensive corpus than the books found in this division today. According to the evidence from $11 \mathrm{QPs}^{\mathrm{a}} 27: 11$, the Psalms may have been included, since they were all attributed to David through נבואה, "prophecy" (see also 4 Macc. 18:10-19). ${ }^{32}$ Furthermore, Klaus Koch argues that Daniel may also have been included with the Prophets at this stage. ${ }^{33}$ In any case, this two-part division seems to represent the mainstream per-

the Dead Sca Scrolls and Related Literature; Grand Rapids: Eerdmans, 1999); The Bible as Book: The Hebrew Bible and the Judaean Desert Discoveries (ed. Edward D. Herbert and Emanuel Tov; London: British Library, 2002); James C. VanderKam, "Questions of Canon Viewed through the Dead Sea Scrolls," in McDonald and Sanders, Canon Debate, 91-109; and Florentino García Martínez, "Rethinking the Bible Sixty Years of Dead Sea Scrolls Research and Beyond," in Popović, Authoritative Scriptures in Ancient Judaism, 19-36.

${ }^{31}$ The Pentateuch's ordering of universal history, which basically follows the genealogies in Genesis 5 and 11, clearly lines up with the Maccabean reconsecration of the temple in 164 в.C.E., four thousand years after the creation. See Konrad Schmid, Erzväter und Exodus: Untersuchungen zur doppelten Begründung der Ursprünge Israels innerhalb der Geschichtsbücher des Alten Testaments (WMANT 81; Neukirchen-Vluyn: Neukirchener Verlag, 1999), 20-21; Eng. trans., Genesis and the Moses Story: Israel's Dual Origins in the Hebrew Bible (trans. James D. Nogalski; Siphrut: Literature and Theology of the Hebrew Scriptures 3; Winona Lake, IN: Eisenbrauns, 2010), 18-19.

32 See further 2 Macc 2:13, which refers to an ensemble of Former and Latter Prophets along with Psalms ("The same thing was reported in the writings and memoirs of Nehemiah, along with how he established a library and collected the books about the kings and prophets, as well as the writings of David and the letters of kings about votive offerings"). Regarding 4QMMT", see Reinhard G. Kratz, "Mose und die Propheten: Zur Interpretation von 4QMMT C," in From 4QMMT to Resurrection: Mélanges qumraniens en hommage à Émile Puech (ed. Florentino García Martínez et al.; STDJ 61; Leiden: Brill, 2006), 151-76.

${ }^{33}$ See esp. Koch, "Ist Daniel auch unter den Profeten?" in Die Reiche der Welt und der kommende Menschensohn: Studien zum Danielbuch (Gesammelte Aufsätze 2; Neukirchen-Vluyn: Neu- 
ception of the structure of the biblical Scripture during this period. However, it is probably necessary to differentiate the various notions of Scripture found among the different groups in ancient Judaism. ${ }^{34}$ Scattered references like those in 4QMMT or Luke 24:44 specifically accentuate the Psalms alongside the Law and the Prophets, but they are rare and not necessarily contradictory: the "and" between the Prophets and the Psalms may have an epexegetical instead of an additive meaning.

Furthermore, the oft-cited prologue of Sirach from the final third of the second century в.C.E. provides no counterargument against the fundamental two-part division of Scripture during the surrounding time period. While Sirach does cite writings beyond the Law and the Prophets, they neither have a collective label nor form an official body of "Scripture." The prologue mainly indicates that the book of Sirach sees itself as one of these other writings, the number of which could easily increase if one felt "moved" to do so. ${ }^{35}$ The evidence from Qumran and the NT makes the presence of a third canonical section in the sense of the later Ketuvim unimaginable/unlikely prior to 70 C.E. ${ }^{36}$

What, then, was the impetus for the later three-part canon? Why does the third canonical section, Ketuvim, emerge at all? Why is the connection between the exclusion of texts like Psalms or Daniel from the heretofore more broadly composed Prophets? How do the hermeneutics of scripture change with the new tripartite division of Torah, Nevi'im, and Ketuvim?

There are various theories regarding the origin of the Ketuvim. The standard theory understands the category Ketuvim as a reservoir of additional authoritative literature after the closing of the Prophets. Roger T. Beckwith argues that the Ketuvim originated as an instrument for safeguarding tradition during the Maccabean period. ${ }^{37}$ Albert de Pury and Bernhard Lang view the Ketuvim as an anthology of exemplary Jewish literary genres opposing the pressures of Hellenistic culture. ${ }^{38}$

kirchener Verlag, 1995), 1-15. Koch refers to Matt 24:15; Josephus, C. Ap.; 4QFlor 2.3. See also Beate Ego, "Daniel und die Rabbinen," Jud 51 (1995): 18-32.

${ }^{34}$ See esp. Carr, "Canonization," 22-64.

${ }^{35}$ See Buhl, Kanon, 13-14. In the ancestral hymn of Sirach 44-50, the book of Sirach itself enumerates only the configuration of the Torah and Nevi'im (see Albert de Pury, "Qohéleth et le canon des Ketubim," RTP 131 [1999]: 163-98, 181 n. 25).

${ }^{36}$ See the synopsis in Stephen G. Dempster, “Torah, Torah, Torah: The Emergence of the Tripartite Canon," in Exploring the Origins of the Bible: Canon Formation in Historical, Literary, and Theological Perspective (ed. Craig A. Evans and Emanuel Tov; Acadia Studies in Bible and Theology; Grand Rapids: Baker Academic, 2008), 87-127, esp. 122-24.

${ }^{37}$ Beckwith, The Hebrew Bible Canon of the New Testament Church, and Its Background in Early Judaism (London: SPCK, 1985).

${ }^{38}$ De Pury, "Zwischen Sophokles und Ijob: Die Schriften (Ketubim): Ein jüdischer LiteraturKanon," Welt und Umwelt der Bibel 28 (2003): 25-27; idem, "Le canon de l'Ancien Testament," in Römer et al., Introduction à l'Ancien Testament, 17-39; Lang, "The 'Writings': A Hellenistic Literary Canon in the Hebrew Bible," in Canonization and Decanonization (ed. A. van der Kooij and K. van der Toorn; SHR 82; Leiden: Brill, 1998), 41-65. See also Chapman, Law, 287-89. 
What these theories have in common is their neglect of the generally theological nature of these writings. This is not to propose a fourth theory, especially since the other three are not necessarily incorrect; rather, the theological, argumentative thrust of the Ketuvim should receive greater emphasis. This focus, with all its divergence in detail, reveals that the newly formed Writings provide everyday life application of the Law and the Prophets, which seems to give a hint at the (proto) Pharisaic origins of their formation. ${ }^{39}$

From a canonical perspective, books such as Psalms, Proverbs, Job, and Qoheleth can be read as instructions for pious conduct and flourishing even in the face of life's adversities, which Job both experiences and describes. While all these books exhibit a far wider range of themes and topics if read as stand-alone units, these elements gain prominence when viewed in light of the canon. With corresponding caution, one can characterize the new canonical logic of the sequence Law, Prophets, and Writings as a process of de-eschatologizing of the previous Lawand-Prophets connection that pointed to the Torah's application in history. The historical journey of God with God's people presented in the Torah and the Prophets is counterbalanced by the Ketuvim's focus on the individual and his or her well-being and security in daily life. ${ }^{40}$

Psalm 1, the opening text of the Ketuvim (according, at least, to the majority of attested arrangements of the Hebrew Bible), provides an example of this phenomenon. This psalm seems particularly fitting for this position and goes on to determine the interpretive trajectory for the following Ketuvim: ${ }^{41}$

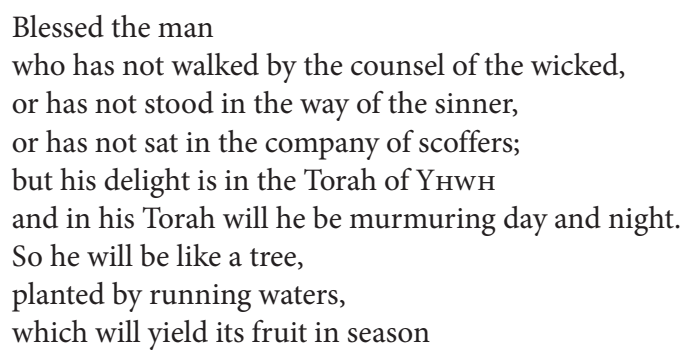

${ }^{39}$ Extrabiblical sources indicate the great interest of the Pharisees in the canon. See Gustav Hölscher, Kanonisch und apokryph: Ein Kapitel aus der Geschichte des alttestamentlichen Kanons (Leipzig: A. Deichert, 1905), 5-6; see also Julius Steinberg, Die Ketuvim-ihr Aufbau und ihre Botschaft (BBB 152; Hamburg: Beltz Athenäum, 2006).

${ }^{40} \mathrm{~A}$ certain countermovement to this tendency marks the positioning of Chronicles at the end of the Ketuvim with the Edict of Cyrus in 2 Chr 36:22-23 and the last statement, ויעל ("Let him go up"), which implies hope in a new exodus and temple.

${ }^{41}$ See Reinhard G. Kratz, "Die Tora Davids: Psalm 1 und die doxologische Fünfteilung des Psalters," ZTK 93 (1996): 1-34; Zenger, "Der Psalter im Horizont von Tora und Prophetie," 11134. Psalm 1 does not seem to have originated specifically for this purpose. 4QFlor 3.14 already knows Psalm 1 (as 3:18 knows Psalm 2). Some manuscripts of Acts 13:33 conspicuously cite Ps 2:7 as a declaration of the "first" Psalm. 
and whose leaves do not wither.

So, in all that he will do, he will be prosperous.

Such is not the case with the wicked;

they are like chaff, which the wind blows away.

Therefore, neither will the wicked stand ${ }^{42}$ in judgment,

nor the sinner in the community of the righteous.

For Yнwн knows the way of the righteous,

but the way of the wicked perishes.

The first Psalm states that those who orient themselves toward the Torah will have successful lives. It is probably deliberate that this text speaks of the Torah as the Torah of Yнwh (not the Torah of Moses), taking up the linguistic usage of the Chronicler. This statement makes it clear that Psalm 1 is subordinate to the Torah, to which the pious must orient themselves. Alongside the explicit references in Psalm 1, implicit references also lend themselves to a canon-theological reading. Psalm 1 first reuses the language of Josh 1:8, where God speaks to Joshua after the death of Moses: ${ }^{43}$

This book of Torah shall not depart from your mouth and you shall murmur on it day and night, so that you may certainly do all that is written in it. For then you will be prosperous in your ways, and then you will have success.

With this reference back to Joshua, Psalm 1 places its readers back into Joshua's position following the death of Moses. One could even say that, on the one hand, Psalm 1 ties itself to the period before the conquest, the point in salvation history when Israel was on the brink of success, thereby reopening all possibilities for each individual reader. On the other hand, Psalm 1 now charges each individual with responsibility: Torah observance applies to each person and each person's wellbeing depends on it. The sphere of accountability does not end with leaders like Joshua and the kings but extends to every person.

The fact that the beginning of the Ketuvim (Psalm 1) commences at the beginning (Joshua 1) rather than the end of the Nevi'im also might mean that the Ketuvim provide a separate, supplementary, and nonprophetic interpretation of the Torah. As Norbert Lohfink has stressed, the logic of a three-part canon is not simply linear in the sense that the Torah, Nevi'im, and Ketuvim successively endorse one another. ${ }^{44}$ Texts such as Psalm 1 reveal that the Ketuvim can make direct references to the Torah, virtually bracketing out the Nevi'im.

42 The LXX offers an eschatological interpretation: "neither will the wicked resurrect."

${ }^{43}$ Joshua 1:8 is an integral part of 1:7-9 and cannot be set aside as a later redactional insertion; see the concentric structure in Klaus Bieberstein, Josua - Jordan - Jericho: Archäologie, Geschichte und Theologie der Landnahmeerzählungen Josua 1-6 (OBO 143; Fribourg: Universitätsverlag; Göttingen: Vandenhoeck \& Ruprecht, 1995) 390-91. 481-94.

${ }^{44}$ Lohfink, "Moses Tod, die Tora und die alttestamentliche Sonntagslesung," TP 71 (1996): 
This claim finds support through a second innerbiblical reference in Psalm 1. The imagery of the tree by the streams of water is apparently borrowed from Jer $17: 7-8$, as the many terminological and literary contacts between these two texts clearly suggest: ${ }^{45}$

Blessed is the man who trusts in Үншн and Yнwн becomes his trust! He shall be like a tree planted by the water ${ }^{46}$ that extends its roots by the stream. It shall not fear when heat comes, and its leaves shall be green; in the year of drought it is not anxious, and it does not cease to yield fruit.

The reception of Jer 17:8 in Psalm 1 fundamentally reconfigures the judgment prophecy of Jeremiah. For the Ketuvim, whoever conducts him- or herself in accordance with Psalm 1 does not need to fear the judgment announced and endured by Jeremiah, since such a thing will not happen (or more precisely, for Psalm 1, it will happen not to the Torah-observant but to the wicked).

The reception of Joshua 1 and Jeremiah 17 in Psalm 1, however, does not mean that the predominantly historical theology of the Nevi'im would have been completely set aside. Psalm 1 instead relativizes the impact that this historical theology has with regard to the individual conduct and rewards for the pious. The imagery of the tree planted by the water more clearly evokes temple theology ${ }^{47}$ (see Ps 92:1416; Sir 24; Ezek 47:1-12) and points to the postcultic situation of Psalm 1: the lifegiving divine power of the Temple Mount is tied not to the temple but to Torah study.

Something similar to Psalm 1 is demonstrably present also in biblical wisdom literature when read in the context of the entire canon. ${ }^{48}$ Indeed, it is important that the canonical logic of the Ketuvim advocates scriptural behavior as a postcultic medium salutis for daily life. While this theological position is observable already prior to 70 C.E. (Psalm 1 itself definitely originates before this date and is presupposed at Qumran), ${ }^{49}$ it becomes dominant only in the wake of the violent discontinuation of temple activities by the Romans, whereas the apocalyptic interpretation of the Law and the Prophets becomes strictly apocryphal.

When the cult is destroyed, its soteriological power shifts to the canon: participation in the cult no longer secures salvation. This power is now accorded to conformance to the canon, including the Ketuvim, which contains instruction for

${ }^{45}$ See Bernd Janowski, "Freude an der Tora: Psalm 1 als Tor zum Psalter," EvT 67 (2007): 1831, esp. $24-25$.

${ }^{46}$ Some manuscripts add פלגי before "water" in order to provide a text even more similar to Ps 1:3.

${ }^{47}$ See Jerome F. D. Creach, "Like a Tree Planted by the Temple Stream: The Portrait of the Righteous in Psalm 1:3," CBQ 61 (1999): 34-46.

${ }^{48}$ See further Jack T. Sanders, "When Sacred Canopies Collide: The Reception of the Torah of Moses in the Wisdom Literature of the Second-Temple Period," JSJ 23 (2001): 121-36.

${ }^{49}$ See $n .41$ above. 
everyday life. ${ }^{50}$ Was there a similar development in the relationship between the cult and Scripture six hundred years earlier with the loss of the First Temple in Jerusalem?

\section{Transformation of Temple Theology After the Destruction of Jerusalem in 587 B.C.E.}

Before the destruction of the First Temple by the Babylonians, there was neither canon nor Scripture in Israel. At most, the religious texts used in the cult prior to the end of the period of the monarchy were normative texts such as Deuteronomy. Like Psalm 24, the famous Zion hymn of Psalm 48 provides an example of a religious cultic text. This psalm is an exponent of the Jerusalem cult tradition that represented a quasi-religious national orthodoxy during the period of the monarchy. ${ }^{51}$ The deity Yнwн sits enthroned as king on Zion. This divine presence guarantees the protection and security of Jerusalem and Judah. The cultic recitation of the psalm functioned ritually both to reassure and to secure this concept. Its declaration thus reinforced it and maintained its validity.

The destruction of Jerusalem and its temple in 587 B.c.E. amounted to an event that was both improbable and generally inconceivable according to Psalm 48. The theological program of the Jerusalem cult tradition represented by Psalm 48 was falsified through this historical event. Nevertheless, the cultic strand of tradition was not simply expunged. It appeared later in modified form in the Priestly source, which transferred the sanctuary from Zion to the mythical Sinai, setting it in the prehistory of Israel and removing from it any political turmoil. ${ }^{52}$ Prophetic tradi-

\footnotetext{
${ }^{50}$ This does not preclude the possibility that some of the Ketuvim are aimed specifically at providing ritual legitimacy, for example, especially in questions of the calendar; see James W. Watts, "Ritual Legitimacy and Scriptural Authority," JBL 124 (2005): 401-17; Donn F. Morgan, Between Text and Community: The Writings in Canonical Interpretation (Minneapolis: Fortress, 1990); James A. Sanders, Torah and Canon (2nd ed.; Eugene, OR: Cascade, 2005), 111-35.

${ }^{51}$ See Odil H. Steck, Friedensvorstellungen im alten Jerusalem: Psalmen, Jesaja, Deuterojesaja (ThSt 111; Zurich: Theologischer Verlag, 1972), as well as the articles in Keel and Zenger, Gottesstadt und Gottesgarten; Friedhelm Hartenstein, Das Archiv des verborgenen Gottes: Studien zur Unheilsprophetie Jesajas und zur Zionstheologie der Psalmen in assyrischer Zeit (BiblischTheologische Studien 74; Neukirchen-Vluyn: Neukirchener Verlag, 2011).

${ }^{52}$ For the "prehistoric" character of the Priestly source, see Norbert Lohfink, "Die Priesterschrift und die Geschichte," in Congress Volume: Göttingen, 1977 (ed. J. A. Emerton; VTSup 29; Leiden: Brill, 1978), 183-225; repr. in idem, Studien zum Pentateuch (SBAB 4; Stuttgart: Katholisches Bibelwerk, 1988), 213-53; Ernst A. Knauf, "Der Exodus zwischen Mythos und Geschichte: Zur priesterschriftlichen Rezeption der Schilfmeer-Geschichte in Ex 14," in Schriftauslegung in der Schrift: Festschrift für Odil Hannes Steck zu seinem 65. Geburtstag (ed. Reinhard. G. Kratz et al.; BZAW 300; Berlin/New York: de Gruyter, 2000), 73-84; idem, "Der Priesterschrift und die Geschichten der Deuteronomisten," in The Future of the Deuteronomistic History (ed. T. Römer;
} 
tions prior to $\mathrm{P}$ established and appropriated direct ties to the cult tradition. Jeremiah 6:22-26 offers an especially clear example. This text reuses and inverts several themes from Psalm $48 .^{53}$ The enemies assailing Zion are no longer struck with fear and trembling ("pains [חיל] like a woman in labor [כיולדה]") as found in Ps 48:5-7. This terror (cf. Jer 6:24: "pains [חיל]] like a woman in labor [כיולדה]") falls instead upon the people of Jerusalem, confronting them with an experience earlier reserved only for their enemies. The text no longer depicts Zion as an impregnable cosmic mountain but as a vulnerable, violated woman. This portrayal of Jerusalem as a woman in the Hebrew Bible first appears in Jeremiah and Lamentations, probably in response to the destruction of Jerusalem. ${ }^{54}$

Jeremiah 6 is not a cultic text but a text that reflects on the loss of the cult. This observation reflects a crucial shift in the understanding of the text itself: unlike Psalm 48, Jeremiah 6 is not a religious text within a cultic-religious system. It instead marks out a possible notion of Scripture relevant for a community outside the context of a mainly cultic environment. No longer does this text have the air of doxology, but rather one of lamentation. This very point highlights the fundamental transformation that has occurred: the texts no longer celebrate the gloria dei, which persists without them, but they instead provide their authors and readers with a new outlook on a henceforth hidden yet available God: God becomes present when invoked. This linguistic gesture of invocation actually becomes the "place" where an experience of God is possible, a trajectory that will continue later in the construction of the Psalter into a literary sanctuary. ${ }^{55}$

BETL 147; Leuven: Peeters, 2000), 101-18. For the function of "Mount Sinai" in the Priestly source, see Konrad Schmid, "Der Sinai und die Priesterschrift," in "Gerechtigkeit und Recht zu üben" (Gen 18,19): Studien zur altorientalischen und biblischen Rechtsgeschichte, zur Religionsgeschichte Israels und zur Religionssoziologie. Festschrift für Eckart Otto zum 65. Geburtstag (ed. Reinhard Achenbach and Martin Arneth; Beihefte zur ZABR 13; Wiesbaden: Harrassowitz, 2010), $114-27$.

${ }^{53}$ See the detailed argument in Schmid, Buchgestalten, 332-33; idem, Literaturgeschichte, $129-30$.

${ }^{54}$ See Aloysius Fitzgerald, "The Mythological Background for the Presentation of Jerusalem as a Queen and False Worship as Adultery in the OT," CBQ 34 (1972): 403-16; idem, "BTWLT and BT as Titles for Capital Cities," CBQ 37 (1975): 167-83; Odil H. Steck, "Zion als Gelände und Gestalt: Überlegungen zur Wahrnehmung Jerusalems als Stadt und Frau im Alten Testament," ZTK 86 (1989): 261-81; repr. in idem, Gottesknecht und Zion: Gesammelte Aufsätze zu Deuterojesaja (FAT 4; Tübingen: Mohr, 1992), 126-45; Marc Wischnowsky, Die Tochter Zion: Aufnahme und Überwindung der Stadtklage in den Prophetenschriften des Alten Testaments (WMANT 89; Neukirchen-Vluyn: Neukirchener Verlag, 2001); Christl Maier, "Tochter Zion im Jeremiabuch: Eine literarische Personifikation mit altorientalischem Hintergrund," in Prophetie in Israel: Beiträge des Symposium "Das Alte Testament und die Kultur der Moderne" anlässlich des 100. Geburtstags Gerhard von Rads (1901-1971), Heidelberg, 18.-21. Oktober (ed. Irmtraud Fischer et al.; Altes Testament und Moderne 11; Münster: LIT, 2003), 157-67; eadem, Daughter Zion, Mother Zion: Gender, Space and the Sacred in Ancient Israel (Minneapolis: Fortress, 2008).

${ }^{55}$ See n. 21 above. 
Therefore, one can argue that the prophetic corpus owes its resultant status as Scripture largely to the observable, historical confirmation of the country's demise. This corpus was established as the successor to the preexilic cult religion-the religion whose death generated the prophetic literature's standing as one core element of Israelite religion. ${ }^{56}$ The rise of this literature can be observed in the fact that in Haggai and Zechariah, as well as in Ezra 1-6, the new project of building the Second Temple in the early Persian period required the legitimation and support of prophetic authority: the temple-building project is successful only because of the prophetic support provided by Haggai and Zechariah. ${ }^{57}$ The preexilic subculture of oral prophecy becomes the written foundation for the postexilic religion of early Judaism.

\section{The Canon and the Cult: The Cult-Replacing Functions of Scripture and Canon}

Looking back, how is the gradual sublimation of the cult understandable in the context of an emergent book religion? First, based on the situation at the end of the Second Temple period in 70 C.E., one can maintain that the canon replaced the temple cult to a certain extent (as the rabbis said, "Where the Torah is studied, no temple is necessary"). ${ }^{58}$ At the same time a new cultic connection was established with the canon itself. The handling that the Torah scrolls in rabbinic Judaism exhibits their promotion to the level of sacred objects. This process is observable as early as Neh 8:5-8. Thus, canon and cult are not functionally exchangeable concepts, but the canon can adopt and assimilate particular functions of the cult. ${ }^{59}$

This is not to say that the process was simple. The fact that during the events surrounding 70 C.E. the daily sacrifice persisted until the very end shows that the loss of the temple cult must have been a dramatic turning point. Nevertheless, Israel was thoroughly prepared for a life without sacrifice. Consider, for example, the sapiential critique of the cult and the phenomenon of synagogue worship. The withdrawal of the Qumran community implies that "prayers and a perfect lifestyle" (1QS 9.4-5) could in practice replace the atoning function of sacrifice in some Jewish communities.

\footnotetext{
${ }^{56}$ See further Reinhard G. Kratz, "Die Redaktion der Prophetenbücher," in Rezeption und Auslegung im Alten Testament und in seinem Umfeld: Ein Symposion aus Anlass des 60. Geburtstags von Odil Hannes Steck (ed. Reinhard G. Kratz and Thomas Krüger; OBO 153; Freiburg: Universitätsverlag; Göttingen: Vandenhoeck \& Ruprecht, 1997), 9-27; idem, Die Propheten Israels (Munich: C. H. Beck, 2003).

${ }^{57}$ See Thomas Krüger, "Esra 1-6: Struktur und Konzept" BN 41 (1988): 65-75.

${ }^{58}$ See Schreiner, "Wo man Tora lernt," 371-92.

${ }^{59}$ See n. 30 above.
} 
Additionally, Israel had lost its temple once before and had, therefore, already practiced a postcultic way of life to some degree. Texts such as Jer 41:4-5 might suggest that the loss of the temple did not put a complete end to cultic practice related to the temple:

On the second day after the murder of Gedaliah, before anyone had heard of it, eighty men from Shechem, Shiloh, and Samaria arrived with shaved beards, torn clothing, and self-inflicted wounds. With them, they had incense and offerings to present at the Temple of YHwH.

By the time of the murder of Gedaliah, the temple had already been destroyed for several years, yet Jer 41:4-5 reports that northern Israelites were coming to deliver their offerings. Apparently even the destroyed temple square could still fulfill cultic functions. However, a passage like this one cannot obscure the fact that the destruction of the First Temple entailed profound theological consequences, especially with regard to the status of Zion and the temple. These entities were previously viewed as an impregnable cosmic mountain functioning as the location of Yнwн's salvific presence. The metaphor of the woman partially replaces the metaphor of the mountain, and lamentation begins to replace doxology, although these elements still coexist.

The connection to God formerly established by the cult now demands re-conceptualization. Linguistic acts, as suggested by Psalm 24, were already indispensable elements of the cult actions. After the destruction of the First Temple, they become the most essential component for establishing a connection with God. The lament indeed had a preexilic history in the cult: it was embedded in the psalms of lament, which had their counterpart in the Priestly declarations of salvation. Following 586 в.C.E. the lament is removed from this cultic context and begins a linguistic life of its own. It single-handedly takes on a functionally equivalent role of the former cult-the establishment of nearness to God.

The formation of Judaism as a book religion was a process facilitated through the destruction of both temples. ${ }^{60}$ This development did not aim at the substitution of traditional religious elements but rather at their transformation and gradual sublimation. In this process the birth of Judaism, the first book religion, can be detected, and it would eventually become the mother of two further book religions. ${ }^{61}$

\footnotetext{
${ }^{60}$ See Hahn, Zerstörungen des Jerusalemer Tempels.

${ }^{61}$ See n. 3 above.
} 